\title{
Investigation of Relationship between Dimensions of Organizational Performance Promotion and Employees Empowerment
}

\author{
*Seyedh Khadijeh Moafi Madani \\ Department of Educational Management, Tonekabon Branch, Islamic Azad University, Tonekabon, Iran \\ *Corresponding Author E-mail: amirhossein1999@yahoo.com
}

\section{Ghazal Ahmadi}

Ph.D Student Department of Curriculum, Tabriz branch, Islamic Azad University, Tabriz, Iran

\author{
Doi:10.5901/mjss.2015.v6n5s2p610
}

\begin{abstract}
The main target of this research is to investigate relationship between dimensions of promotion of organizational performance and employees' empowerment. The research is a descriptive-correlation study. Statistical population of the research included all employees of National Bank in Tonekabon City. 120 employees were selected by means of single-stage cluster random sampling. A questionnaire for evaluation of dimensions of promotion of organizational performance containing 35 questions and Spritzer's empowerment questionnaire (1995) containing 12 questions was used for collecting data. Validity of the questionnaires was verified by assistant professors and other experts. Reliability of the questionnaires was calculated by means of Cronbach's alpha. It was equal to 0.85 for organizational performance promotion questionnaire and equal to 0.86 for empowerment questionnaire. Data were analyzed by means of Pearson correlation coefficient and multivariate regression. The results showed that there is a positive and significant relationship between dimensions of organizational performance promotion (organizational learning, knowledge management, organizational performance) and employees' empowerment in branches of national bank in Tonekabon $(p<0.01)$. Knowledge management had the greatest role in prediction of employees' empowerment.
\end{abstract}

Keywords: promotion of organizational performance, organizational learning, knowledge management, organizational performance, employees' empowerment

\section{Statement of Problem}

Organizational performance is a general construct which refers to the quality of organizational operation. The most famous definition for performance was provided by Nili et al (2002): "'the process of specification of the quality of effectiveness and efficiency of previous actions". According to this definition, performance is divided into two elements: 1. Efficiency, which describes the quality of organizational use of resources in production of services or products, i.e. relationship between real and expected combination of inputs for production of specified outputs and 2. Effectiveness, which describes the degree to which organizational goals have been fulfilledThese targets are usually in the form of consistency (compatibility between outputs and customers' needs), accessibility (aspects like frequency, priority and physical distance) and quality (degree of implementation of necessary standards) (Dollery and Worthington, 2004). Molin (2007) emphasized on value of performance measurement in his definition: "evaluation of the quality of management of organizations and their values for customers and benefits" (as quoted from Amartunga, 2003). In addition, as Nili states (2005), value creation for beneficiaries plays an important role in organizational success. Undoubtedly, managers need to know how their key beneficiaries perceive them and this helps them with measuring beneficiaries perceptions in definition of performance. One of the dimensions of organizational performance promotion is knowledge management. Knowledge management does not simply refer to management of knowledge but it deals mainly with management and creation of common culture which improves sharing, application and creation of knowledge and improves organizational performance (Ramezani, 2004). Knowledge sharing is a complex but valuable activity and is the foundation of many knowledge management strategies. Knowledge management has received a lot of attention in Iranian and foreignorganizations within the past few years because it is one of the main way for competitive advantage (Lajevardi, 2007). Another variable which influences promotion of organizational performance is organizational learning. Organizational learning is able to revive an organization. The following items can influence organizational learning: a) 
individual learning: learning in individual level, an individual's knowledge acquisition using mental and cognitive processes, understanding them, interpreting them, and doing experiences with them and regulation of their behaviors based on the results. Therefore, intuition and interpretation are individual events. An organization cannot have intuition and simultaneously interpret. Individuals have intuition under the name of organization and interpret. B) team learning: this refers to sharing one's knowledge in a team or group, interpreting with each other and acquiring a group conception (Downport, 2003). Employees can do their duties well when they have necessary knowledge, skills and abilities and when they know organizational targets. Empowerment is a process which can help managers in this regard. Human resource is the main asset of any organization. Quality and empowerment of human resource is the main factor for organizational survival. Empowered human resource yields to empowered organization. From Drucker's viewpoint, economic growth relies on employees' empowerment. An empowered organization is an environment in which employees cooperate with each other in different groups. Employees' empowerment is the main attempt of managers in innovation, deconcentration and elimination of bureaucracy in organizations (Khanalizadeh et al, 2010). Each factor which improves banks performance can have an important influence on economy and society. Considering the fact that organizational learning in a bank can help an organization with fulfillment of missions, the author tries to investigate relationship between dimensions of organizational performance promotion and employees' empowerment in branches of National Bank in Tonekabon City. We hope the results of the present research can be effective in recognizing the importance of this relationship.

\section{Research Hypotheses}

1. There is a significant relationship between organizational learning and employees' empowerment.

2. There is a relationship between knowledge management and employees' empowerment.

3. There is a relationship between organizational performance and employees' empowerment.

\section{Methodology}

\subsection{Statistical population, sample, sampling method and estimation of sample size}

Research methodology is descriptive correlation.

Statistical population of the research included all employees of National Bank branches in Tonekabon City. 120 employees were selected by means of single-stage cluster sampling method.

\subsection{Data collection instrument}

1. Organizational performance promotion dimensions questionnaire: this questionnaire contains 35 questions and aims to investigate dimensions of organizational performance promotion (organizational learning, knowledge management and organizational performance). Validity of the questionnaire was verified by assistant professors and advisors. Reliability coefficient was equal to 0.89 by means of Cronbach's alpha.

2. Spiretzer's empowerment questionnaire: a questionnaire designed by Spritzer (1995) was used for measuring employees' empowerment. This questionnaire contains 4 subscales: significance, competency, autonomy and effectiveness. It contains 12 items and 3 items were considered for each subscale. The validity of the questionnaire was verified by experts. Cronbach's alpha for this questionnaire was equal to 0.86 .

In order to analyze data, indices like frequency, mean, standard deviation, graphs and tables were used in descriptive statistical analysis. In inferential statistics, Pearson correlation coefficient and multivariate regression analysis were used.

\section{Findings}

Correlation and concurrent multiple regression method was used for investigation of the hypotheses. Regression is a statistical method which allows finding the score of an individual in a particular variable by means of the score of that individual in several other variables in case they are correlated. As correlation increases, the scores are closer to regression line and the prediction will be more exact.

Characteristics of descriptive statistics have been summarized in table 1. 
Table 1: descriptive indices for research variables $(n=120)$

\begin{tabular}{|l|c|c|}
\hline Variables & Mean & Standard Deviation \\
\hline Empowerment & 54.38 & 9.789 \\
\hline Organizational Learning & 43.95 & 10.489 \\
\hline Knowledge Management & 34.23 & 7.826 \\
\hline Organizational Performance & 42.46 & 9.597 \\
\hline
\end{tabular}

As it can be seen, mean value of empowerment variable is equal to 54.38 and its standard deviation is equal to 9.789 . the greatest mean value belongs to organizational learning (43.95) and its standard deviation is equal to 10.489 and the lowest mean value belongs to knowledge management (34.23) and its standard deviation is equal to 7.826 .

We used the results of correlation coefficient test for investigation of the hypotheses.

Table 2: matrix for correlation coefficient between empowerment and predicting variables

\begin{tabular}{|l|c|c|c|}
\hline Variable & $\mathbf{1}$ & $\mathbf{2}$ & $\mathbf{3}$ \\
\hline Empowerment & $.333^{* *}$ & $.388^{* *}$ & $.356^{* *}$ \\
\hline Predicting Variables & & & \\
\hline 1. organizational Learning & - & $.680^{* *}$ & $.774^{* *}$ \\
\hline 2. Knowledge Management & - & - & $.667^{* *}$ \\
\hline 3. Organizational Performance & - & - & - \\
\hline
\end{tabular}

$P^{\star}<0.05, p^{* *}<0.01$

We used partial correlation and stepwise regression analysis for determining the bestpredictor of empowerment. It must be mentioned that only knowledge management enters the model. The results have been summarized in table 4 .

Table 3: multiple correlation coefficient and multiple correlation square for organizational learning, knowledge management and organizational performance in prediction of empowerment

\begin{tabular}{|l|l|c|c|c|c|c|}
\hline Stage & Predicting variable & $\mathbf{R}$ & R Square & Adjusted R Square & 118,1( change f & Significance level \\
\hline Empowerment & $\begin{array}{l}\text { Knowledge management } \\
\text { Kand }\end{array}$ & .388 & .151 & .143 & 20.928 & $0 / 000$ \\
\hline
\end{tabular}

According to table 3 , it can be seen that knowledge management enters the model in step 1 and this variable can predict $14 \%$ of the variance $\left(R^{2}=0.143\right)$.

Therefore, it can be concluded that knowledge management can predict independent variable. Therefore, regression equation can be generalized to the whole society.

The results of determination of coefficients of regression analysis and determination or significant prediction for independent variable and formulation of regression equation have been summarized in table 4 .

Table 4. Coefficients of standard and non-standard regression analysis for prediction of empowerment

\begin{tabular}{|l|l|c|c|c|c|c|}
\hline Dependent Variable & Statistical Index Predicting Variable & Unstandardized Coefficients & Std. Error & Standardized Coefficients Beta & $\mathrm{t}$ & $\mathrm{P}$ \\
\hline \multirow{2}{*}{ Empowerment } & Fixed & 31.789 & 4.591 & - & 6.924 & .000 \\
\cline { 2 - 7 } & Knowledge Management & .332 & .148 & .260 & 2.248 & .026 \\
\hline
\end{tabular}

Considering the results summarized in table 4 and significance of $\mathrm{F}$ in variance analysis table and $\mathrm{t}$ in the above table, regression equation is related to a predictor i.e. knowledge management. Considering slope coefficients (column B), equation for prediction of empowerment using values of knowledge management variable is as follows:

Empowerment $=31.789+0.332$ (knowledge management)

Considering the slope value, as values of knowledge management variable increases, higher values are predicted for empowerment. According to this correlation analysis, it can be concluded that knowledge management is the only useful predictor of variations of empowerment $\left(R^{2}=14 \%\right)$. 


\section{Conclusion and Discussion}

In the following sentences, we analyze the results of hypotheses tests.

3. first hypothesis states that there is a relationship between organizational learning and employees' empowerment.

The research results showed that the calculated correlation coefficient between organizational learning and employees' empowerment is significant in $(p<0.01)$ level $(r=0.333, P=0.000)$. this shows that there is a positive and significant relationship between organizational learning and employees' empowerment. In other words, as organizational learning increases, employees' empowerment is also increased.

The results of the present research are consistent with the results of studiesconducted by Rahnavard (2008), Afjeh and Miri (2009), Kaffashi and HatamiNejad (2009), Khanalizadeh et al (2010), Moshabbaki et al (2012), Dihulan and Philips (2004), Ergenli (2007) and Chand et al (2007).

The results showed that as organizational learning increases, the organization will be able to become more compatible with environment and thereby will be more successful. Employees' competencies for doing hard tasks increase and scientific base and power of the organization will be also improved. Undoubtedly, employees' empowerment will be improved as employees scientific levels increase.

4. the second hypothesis states that there is a relationship between knowledge management and employees' empowerment.

The results of the research showed that the calculated correlation coefficient between knowledge management and employees' empowerment is significant in $(p<0.01)$ level $(r=0.388, p=0.000)$. this shows that there is a significant and positive relationship between knowledge management and employees' empowerment. In other words, as knowledge management increases, employees' empowerment will be also increased.

The results of the present research are consistent with the results of Moshabbaki et al (2012), Damghanian et al (2013), Asgari et al (2012), Nodarapati (2003), Real et al (2006) and Chand et al (2007).

The results showed that knowledge management identifies and specifies intellectual properties and creates new knowledge outside an organization and facilitates access to information, sharing appropriate processes and access to information technology inside an organization and therefore helps employees with accessing to necessary knowledge when and where they need it and transfer the knowledge to their colleagues and manage their knowledge and this is the very empowerment.

5. the fourth hypothesis states that there is a relationship between organizational performance and employees' empowerment.

The results showed that the calculated correlationcoefficient between organizational performance and employees' empowerment is significant in $(p<0.01)$ level $(r=0.356, P=0.000)$. this shows that there is a positive and significant relationship between organizational performance and employees' empowerment. In other words, employees' empowerment will increase if organizational performance increases.

The results of the present research in this hypothesis regard are consistent with the results of studies conducted by Afjeh and Miri (2009), Moshabbaki et al (2012), Norouzi (2005), Nodarapati (2003), Duting et al (2003), Li HesVitra (2004), Chand et al (2007) and Skerlavj et al (2007).

The results showed that organizations can influence both organizational learning and management of organizational oblivion by adjusting physical assets, organizational structure, current affairs and regulations and changing customers' understanding. Therefore, they can improve their performances. As organizational performance is more effective, it increases effectiveness and efficiency. The immediate result of this is increasing employees' empowerment. That is to say, the employeetries to find correlation between employees and their group dependence instead of independence or dependence. Therefore, managers are proposed to provide employees with training, motivation, participatory management style, granting more freedom of action in occupational performance, emotional supports, and reduction in anxiety in work environment and opportunity for acquiring occupational skills which play important roles in increasing employees' empowerment. This will improve employees' empowerment.

\section{References}

Afjeh, Ali Akbar; Miri, Abdorreza, a model for promoting employees' performance in Iranian parts manufacturing industry, quarterly of Iranian management sciences, fourth year, number 14, summer 2009, pp: 149-169.

Amaratunga, D. and Baldry, D.(2002) «Moving from performance measurement to performance management», Facilities, Vol. 20 . No. 
5/6, Care, Open University Press, Buckingham.

AsgariBahman, Pour SoltaniZarandi, Hosein; and Moshiri, Keivan (2014). Relationship between organizational learning and psychological empowerment of employees in Central Department of Sports and Youths, Tehran province, journal of management studies, 179-193.

Chand, M., India, K. and Katou, A. A.(2007) «The impact of HRM practices on organisational performance in the Indian hotel industry», Employee Relations, Vol. 29 No. 6, p. 576-594.

Damghanian, Hosein et al (2013). Investigation of the influence of information technology on knowledge management with mediating role of empowerment in National Iranian Drilling Company, journal of IT management, period 5, number 4, pp: 85-102.

Davenport, T.H. and Glaser, J. (2002) Just-in-time delivery comes to knowledge management. Harvard Business Review 80(7), 107-111

De Holan P.M ,Phillips N. Remembrance of things past: The dynamics of organizational forgetting. Management Science 2004; 50: 1603-13.

Dewettinnck, K. (2003). Psychological Empowerment in the workplace, reviewing the empowerment effects on critical work outcomes, Vlerick Leuven Gent Working Paper Series, 29,138.

Dollery, B.E. and Worthington, A.C.(1996) «The Evaluation of Public Policy: Normative Economic Theories of Government Failure», Journal

Ergenli, A., Saglam, G \& Metin, S. (2007). Psychological empowerment and its relationship to trust in immediate managers, Journal of Business Research, 60,41-49.

Khanalizadeh, Roghayyeh (2010), relationship between empowerment and organizational learning (case study: Tarbiyat Modarres university), journal of change management, second year, number 3, pp: 21-45).

Ramezani, Ehsan (2004), knowledge management process. Tadbir monthly, number 147.

Rahnavard, F. A (2003). Employees empowerment, a step towards customer orientation, journal of management and development, number 59 .

Shafi, Arezou (2006). "relationship between employees' empowerment and organizational learning in national Iranian petroleum products distribution company". Master degree thesis, faculty of management, Tehran University.

Kaffashi, MajidHtamiNejad, Rahim (2009). Investigation and clarification of factors affecting employees' empowerment in remedy department of Organization of Social Security in Golestan province, journal of social research, period 2, number 5, pp: 63-95.

Lajevardi, SeyyedJalil; Khan Babayee, Ali (2007); "investigation of factors which facilitate knowledge management in working teams (case study: Agriculture Bank)", management knowledge quarterly, year 20, number 76, page 86, spring, 97-116.

Lehesvitra T. Learning to Forget and Forgetting to Learn. Development and Learning in Organizations 2004; 18(6):26-29.

Moshabaki A, Andalib Ardakani N, Andalib Ardakani D. [The impact of leadership styles on Organizational forgetting: new approach in knowledge management]. Journal of Health AdministraӨon 2011; 14 (44):41-54[Persian]

Neely, A.D., Adams, C. and Kennerley, M.(2002) The Performance Prism: The Scorecard for Measuring and Managing Stakeholder Relationships, Financial Times/Prentice Hall, London.of Interdisciplinary Economics, 7, p. 27-39.p. 217-223. perspective», Journal of Cost Management, January/February.

Norouzi, Mojtaba (2005). "investigation of relationship between psychological factors of employees' empowerment and organizational performance in branches of Mellat Bank in Tehran", master degree thesis, Tehran University.

Nudurupati, S.S.(2003)Management and business implications of IT supported performance measurement, PhD thesis, University of Strathclyde, Glasgow.

Skerlavaj M, Sstemberger MI, Skrinjar R, Dimovski V. Organizational learning culture- the missing link between business process change and organizational performance?. Int. J. production economics. 2007; (106):346-367. 29.

Spreitzer, Gretchen M . (1995) "Psychological Empowerment in the Workplace: Dimensions, Measurement and Validation"; The Academy of Management Journal, Vol .38 No .5 